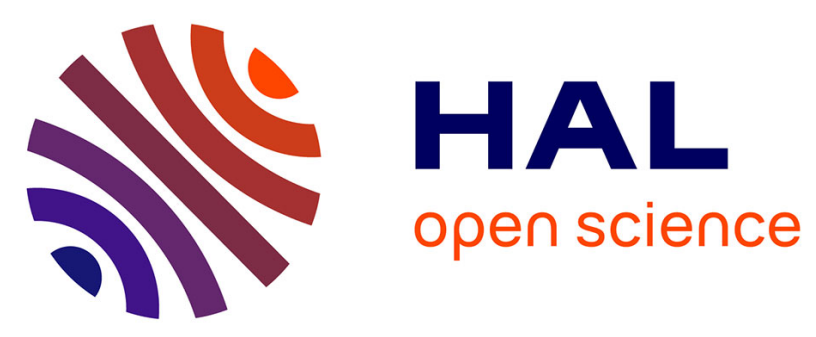

\title{
New data on some crickets of the subfamilies Landrevinae, Phaloriinae and Podoscirtinae (Orthoptera: Grylloidea) from Laguna (Philippines: Luzon Island)
}

Ming Kai Tan, Andrei V Gorochov, Jessica B. Baroga-Barbecho, Sheryl A Yap

\section{To cite this version:}

Ming Kai Tan, Andrei V Gorochov, Jessica B. Baroga-Barbecho, Sheryl A Yap. New data on some crickets of the subfamilies Landrevinae, Phaloriinae and Podoscirtinae (Orthoptera: Grylloidea) from Laguna (Philippines: Luzon Island). 2020. hal-02946324

\author{
HAL Id: hal-02946324 \\ https://hal.science/hal-02946324
}

Preprint submitted on 23 Sep 2020

HAL is a multi-disciplinary open access archive for the deposit and dissemination of scientific research documents, whether they are published or not. The documents may come from teaching and research institutions in France or abroad, or from public or private research centers.
L'archive ouverte pluridisciplinaire HAL, est destinée au dépôt et à la diffusion de documents scientifiques de niveau recherche, publiés ou non, émanant des établissements d'enseignement et de recherche français ou étrangers, des laboratoires publics ou privés. 


\title{
New data on some crickets of the subfamilies Landrevinae, Phaloriinae and Podoscirtinae (Orthoptera: Grylloidea) from Laguna (Philippines: Luzon Island)
}

\author{
Running title: new Grylloidea from Luzon
}

Ming Kai $\operatorname{Tan}^{1} *$, Andrei V. Gorochov ${ }^{2}$, Jessica B. Baroga-Barbecho ${ }^{3} \&$ Sheryl A. Yap ${ }^{4,5}$

${ }^{1}$ Institut de Systématique, Evolution et Biodiversité (ISYEB), Muséum national d'Histoire naturelle, CNRS, SU, EPHE, UA, 57 rue Cuvier, CP 50, 75231 Paris Cedex 05, France. Email: orthoptera.mingkai@gmail.com

${ }^{2}$ Zoological Institute, Russian Academy of Sciences, 1 Universitetskaya Emb., St Petersburg 199034, Russia.Email: orthopt@zin.ru

${ }^{3}$ Office of the Vice Chancellor for Research and Extension, University of the Philippines Los Baños, College Laguna, 4031 Philippines. Email: jbbaroga@up.edu.ph

${ }^{4}$ Institute of Weed Science, Entomology, and Plant Pathology, College of Agriculture and Food Science, University of the Philippines Los Baños, College, Laguna, 4031 Philippines. Email: sayap3@up.edu.ph

${ }^{5}$ Museum of Natural History, University of the Philippines Los Baños, College, Laguna, 4031 Philippines

* Corresponding author

\begin{abstract}
Recent orthopteran sampling at Laguna in Luzon Island of the Philippines revealed noteworthy crickets from the subfamilies Landrevinae, Phaloriinae and Podoscirtinae. We describe three species new to science from the subfamily Podoscirtinae: Mnesibulus laguna $\mathbf{n}$. sp., Mistshenkoana matcha $\mathbf{n}$. sp. and Mistshenkoana sursa $\mathbf{n}$. sp. We record new locality and complete the genitalia description of Phaloria (Phaloria) modulator (Saussure, 1878), previously described with incomplete parts of genitalia in the holotype. We also differentiate Duolandrevus (Jorama) curtipennis Chopard, 1937 from Laguna which varies slightly from the subspecies from Palawan and Mindoro.
\end{abstract}

Key words: Gryllidae, new species, Southeast Asia, taxonomy

\section{Introduction}

The Philippines remains a hotspot for new species discovery of Orthoptera, as sampling in this archipelago is fragmented spatially and temporally (Tan et al., 2017). In the last four years, as many as 15 new species have been reported from across the phylogeny, ranging from pygmy grasshoppers (e.g., Skejo \& Caballero, 2016; Tan et al., 2019a), scaly crickets (e.g., Tan et al., 2019b), raspy cricket (e.g., Ingrisch, 2018), true crickets (e.g., Robillard \& Yap, 2015; Gorochov, 2016; BarogaBarbecho et al., 2016, 2019; Tan et al., 2019c, 2019d) and three katydids (e.g., Tan et al., 2018). As more materials are assembled and more attention given, more new species can be discovered. Crickets of the subfamilies Landrevinae, Phaloriinae and Podoscirtinae are such examples. These plantdwelling crickets are speciose in Southeast Asia, and species are generally morphologically very similar. Species are generally identified and delimited using genitalia morphology, typically in the epiphallic processes, ectoparameres and rachis, which exhibits intraspecific stability and distinct interspecific differences (Gorochov, 2015). However, a small amount of materials is available for many of these species, making it difficult to examine intra-specific variations thoroughly. Recent collections of orthopterans at Laguna in Luzon Island enable us to re-examine the taxonomy of Duolandrevus (Jorama) curtipennis Chopard, 1937 and Phaloria (Phaloria) modulator (Saussure, 1878), as well as to describe new species fof Podoscirtini and Aphonoidini from the subfamily Podoscirtinae: Mnesibulus laguna $\mathbf{n}$. sp., Mistshenkoana matcha $\mathbf{n}$. sp. and Mistshenkoana sursa $\mathbf{n}$. sp. 


\section{Materials and Methods}

Orthopteran surveys were done by M. K. Tan, J. B. Baroga-Barbecho and S. A. Yap in Laguna between 2018 and 2019: Mount Makiling (Los Baños) between 10 and 11 April 2018; University of Philippines (UP) Land Grant (Barangay Ilaya Norte, Paete) (Tan et al., 2020: Fig. 1) between 11 and 12 May 2019 and between 6 and 7 September 2019. Opportunistic sampling and sweep-netting were conducted during daytime (0830 to 1500 hours) and/or during night-time (1930 to 2300 hours). Whenever possible, in-situ images were taken using a Canon EOS 500D digital SLR camera with a compact-macro lens EF $100 \mathrm{~mm}$ f/2.8 Macro USM and Canon Macro Twin Lite MT-24EX was used for lighting and flash.

The specimens were preserved in absolute analytical grade ethanol and later pinned and dry-preserved. A single hind leg was preserved in absolute analytical grade ethanol for future molecular work. Closeup images of habitus and morphological features were done using a Canon EOS 700D digital SLR camera with a macro photo lens MP-E 65mm f/2.8 USM (1-5×) with Canon Macro Twin Lite MT24EX used for lighting and flash.

Male genitalia were dissected from softened specimens and were removed by squeezing the cerci against one another laterally. The male genitalia were then cleaned using aqueous $\mathrm{KOH}$ and subsequently preserved in glycerine. Photographs of male genitalia were done with a binocular microscope Leica MZ16 with AmScope Microscope Eyepiece Camera (MU1000, 10 MP Aptina Colour, CMO50) attached via an AmScope FMA050 fixed microscope adaptor and the montage software AMScope version $\times 64,3.7$. Image editing was accomplished using Adobe Photoshop CC2014. Terminology used to describe the male genitalia follows Tan \& Kamaruddin (2016), Tan \& Wahab (2017) and Tan et al. (2019).

Classification and nomenclature of species was based on the OSF (Cigliano et al., 2020). All specimens collected were deposited in the University of the Philippines Los Baños Museum of Natural History (UPLBMNH) and the Zoological Reference Collection (ZRC), Lee Kong Chian Natural History Museum, Singapore.

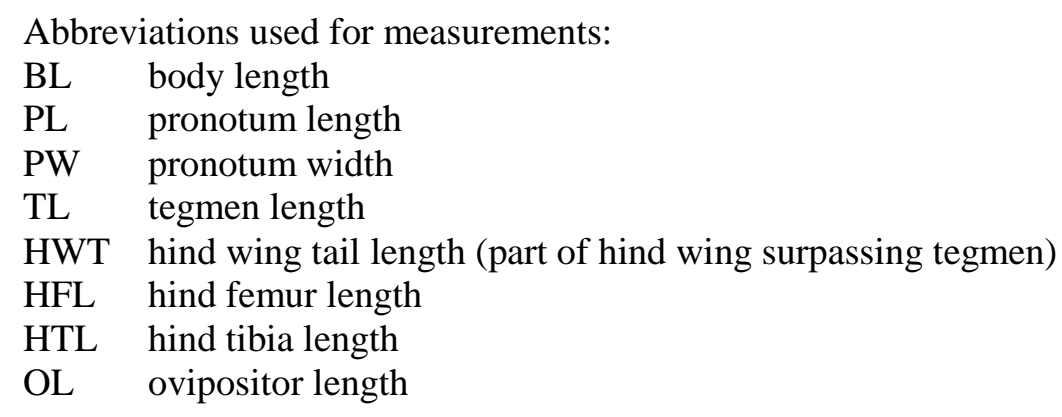

Abbreviations for museums and collections:

$\begin{array}{ll}\text { DORSA } & \text { German Orthoptera collections database, SysTax } \\ \text { MfN } & \text { Museum für Naturkunde, Berlin, Germany } \\ \text { MNHN } & \text { Muséum national d'Histoire naturelle, Paris, France } \\ \text { NHMUK } & \text { Natural History Museum, London, U.K. } \\ \text { UPLBMNH } & \text { University of the Philippines Los Baños Museum of Natural History, Philippines } \\ \text { ZRC } & \begin{array}{l}\text { Zoological Reference Collection, Lee Kong Chian Natural History Museum, } \\ \text { Singapore }\end{array}\end{array}$

\section{Results}

\section{Subfamily Landrevinae}


Genus Duolandrevus Kirby, 1906

Gorochov, 1996: 35; Gorochov, 2016: 25

Remarks. So far, 86 species from eight subgenera are known (Cigliano et al., 2020). Gorochov (2016) provides a key to subgenera.

\section{Subgenus Jorama Otte, 1988}

Otte, 1988: 316; Gorochov, 1996: 40; Ma et al., 2015: 445; Gorochov, 2016: 26

Remarks. This subgenus is characterised by the head moderately depressed dorsoventrally; male anal plate with widely rounded or widely truncate apex and without strong setae directed upwards at apex or on dorsum along median part of its posterior edge; the male genitalia with posterolateral epiphallic lobes not widened and having numerous small denticles or tubercles (Gorochov, 2016). Eight species are known from the Philippines, New Guinea, Taiwan and Lesser Sunda Islands (Cigliano et al., 2020). These species are typically differentiated by the shape of male metanotal gland and male genitalia (particularly the shape of posterolateral epiphallic lobes and ectoparameres). Three species are known in the Philippines (Cigliano et al., 2020): Duolandrevus (Jorama) curtipennis Chopard, 1937 of Palawan and Mindoro; Duolandrevus (Jorama) isagorensis (Otte, 1988) of Camarines Sur; and Duolandrevus (Jorama) palawanensis (Otte, 1988) of Palawan.

\section{Duolandrevus (Jorama) curtipennis Chopard, 1937}

(Fig. 1)

Chopard (1937): 139; Otte (1988): 317; Gorochov (1996): 40; Gorochov (2016): 69

Material examined. 1 male (UPLG.19.52): Philippines, Luzon Island, Laguna, Paete, Barangay Ilaya Norte, UP Land Grant, N14.40035, E121.54249, 317.8 \pm 5.8 m, 1936 hours, hiding underneath tree trunk, 6 September 2019, coll. M. K. Tan, J. B. Baroga-Barbecho, C. C. Lucañas and S. A. Yap, pinned and genitalia dissected; 1 male, same locality, 6-7 September 2019, coll. J. B. BarogaBarbecho \& C. C. Lucañas, pinned and genitalia dissected (all UPLBMNH and ZRC).

Distribution. Palawan Island, Mindoro Island, Luzon Island

Comparisons with subspecies curtipennis Chopard, 1937 and mindoro Gorochov, 2016. The male genitalia differs predominantly by the shape of posterolateral epiphallic lobes (p.ep): dorsoexternal process (de.l) of the posterolateral epiphallic lobe not pointing as dorsad as in D. $c$. curtipennis (sensu Gorochov, 1996: 40) and D. c. mindoro (sensu Gorochov 2016: 69); inner process (i.p) not as long as in D. c. mindoro but not as smoothly curved as in D. c. curtipennis. Other important characters such as shape of ectoparameres and posteromedial lobule of epiphallus very similar among the different populations.

The metanotal glands of the specimens from Luzon are also different from that of D. c. mindoro (sensu Gorochov 2016: 69). We could not examine the metanotal gland of D. c. curtipennis because we could not access the type specimen and that it was not previously described.

Discussion. The slight differences in the genitalia and metanotal gland suggest that the populations from Palawan, Mindoro and Luzon islands can represent either unique species (or subspecies) or a single but variable species. However, we refrain from describing the population from Luzon as another species or subspecies until we have clearer understanding of their species delimitation through acoustic recording and DNA analysis, whenever possible in the future.

\section{Subfamily Phaloriinae}

\section{Genus Phaloria Stål, 1877}


Gorochov, 1996: 60

Remarks. 68 species from four subgenera are currently known (Cigliano et al., 2020).

\section{Subgenus Phaloria Stål, 1877}

Otte \& Alexander, 1983: 372; Gorochov, 1985: 19; Yin \& Liu, 1995: 212; Gorochov, 1996: 60; Desutter-Grandcolas, 2009: 629

Remarks. 18 species are currently known (Cigliano et al., 2020). Two species are known in the Philippines: Phaloria (Phaloria) amplipennis Stål, 1877, Phaloria (Phaloria) modulator (Saussure, 1878) (Cigliano et al., 2020).

\section{Phaloria (Phaloria) modulator (Saussure, 1878)}

(Fig. 2)

Saussure (1878): 537 [685]; Bolívar (1889): 426; Casto de Elera (1895): 219; Kirby (1906): 91; Bruner (1915): 263; Chopard (1968): 360; Gorochov (1996): 60

Type material examined (images). Male holotype (DORSA-BG00002S01), Philippines, Luzon Island, Manila, coll. Meyen (MfN).

Material examined. 2 males (UPLG.19.45, 57): Philippines, Luzon Island, Laguna, Paete, Barangay Ilaya Norte, UP Land Grant, N14.40167, E121.54278, 303.5 $\pm 4.1 \mathrm{~m}, 1649$ hours, N14.39870, E121.54249, 349.0 \pm 5.3 m, 2030 hours, 6 September 2019, on foliage, coll. M. K. Tan, J. B. Baroga-Barbecho, C. C. Lucañas and S. A. Yap, pinned and genitalia dissected (all UPLBMNH and ZRC)

Distribution. This species was described from the Philippines and is currently known only in Luzon Island. The holotype collected from Manila is apparently missing (Hollier et al., 2013). This species was also known from Nueva Cáceres (now part of Naga) (Bruner, 1915). Our material represents the first record of this species in Laguna - albeit not surprising - between Manila in the north of Laguna and Naga in the south of Luzon Island.

Genitalia description (Figs. 2C-E). The genitalia of the male holotype is partly missing, with only the epiphallus (including the bridge, posterolateral epiphallic lobes, posteromedial epiphallic lobule) and ectoparameres present; while rami, rachis (= guiding rod), endoparameres are missing (Gorochov, 1996; Cigliano et al., 2020). The males from Laguna have very similar epiphallic morphology, which are distinct from other congeners: epiphallus (ep) with posterior margin broadly concave posterolateral epiphallic lobes (p.ep) slender, flattened and bent at $90^{\circ}$ internally at the apex with apex subacute; posteromedial epiphallic lobule (m.ep) stout with obtuse apices; ectoparameres strongly sclerotized and stoutly triangular, each with a basal dorsal lobe with subacute apex, taper apically into an acute apex that slightly surpassing posterolateral epiphallic lobes. Here we describe the missing parts of the genitalia: endoparamere (en) forked posteriorly, anterior end straight but not surpassing rami; rami (r) slender, gently curved, anterior end acute; rachis (ra) straight, relatively narrow, anterior end somewhat arrowed-shaped, posterior end truncated and slightly surpassing posteromedial lobule of epiphallus.

\section{Subfamily Podoscirtinae}

\section{Genus Mnesibulus Stål, 1877}

Remarks. 20 species from two subgenera are currently known. Subgenus Amnesibulus Gorochov, 2003 consists of two species from Sulawesi and differs from subgenus Mnesibulus Stål, 1877 by male tegmina with strongly reduced stridulatory apparatus (Gorochov, 2003). 


\section{Subgenus Mnesibulus Stål, 1877}

Remarks. 20 species from China mainland, India subcontinent, Taiwan, Malay Peninsula, Borneo, the Philippines, Sumatra, Java, Sulawesi, Maluka and Lesser Sunda Islands (Cigliano et al., 2020). Mnesibulus (Mnesibulus) lineolatus Stål, 1877, Mnesibulus (Mnesibulus) luzoni Gorochov, 2003, Mnesibulus (Mnesibulus) pallidulus Bolívar, 1889, Mnesibulus (Mnesibulus) splendidulus Stål, 1877 and Mnesibulus (Mnesibulus) strigatipes Bolívar, 1913 are known to occur in the Philippines (Cigliano et al., 2020). Here, we describe another species from the Philippines.

\section{Mnesibulus laguna new species}

(Figs. 3-5)

Material examined. Male holotype (UPLG.19.41), Philippines, Luzon Island, Laguna, Paete, Barangay Ilaya, UP Land Grant, N14.39826, E121.55703, 401.1 \pm 6.5 m.a.s.l., 1417 hours, 6 September 2019, under foliage, coll. M. K. Tan, J. B. Baroga-Barbecho, C. C. Lucañas and S. A. Yap, pinned and genitalia dissected (UPLBMNH).

Female allotype (UPLG.19.64), same locality as holotype, N14.39612, E121.54702, 437.5 \pm 5.6 m.a.s.l., 1105 hours, 7 September 2019, on foliage, coll. M. K. Tan, J. B. Baroga-Barbecho, C. C. Lucañas and S. A. Yap, pinned (ZRC).

Diagnosis. This new species differs from all known congeners by the combination of these characters: abdominal gland with posterior margin of fifth segment rectangularly, emarginated in middle, tubercle on sixth segment with anterior apex triangular and apex; anal plate deeply and narrowly excised in middle, lateral of excision with dense strong setae pointing posteriorly, with a dorsal oval plate slightly surpassing lateral lobes, with posterior margin somewhat truncated; apical epiphallic process large, extending beyond lateral margin of epiphallus, curved anteriorly at apex into a hook-like acute apex; mold of the spermatophore attachment plate with anterior end broadly rounded with two pyriform lateral lobes joined together by a narrow 'bridge' in the middle; apical process of rachis produced well beyond apex of epiphallus, enlarged at apex and unique shape.

Comparison with congeners. The male genitalia is most similar to M. pallidulus Bolívar, 1889 from Sibul in Luzon Island (unclear whether it is referring to Sibul in Bataan or Bulacan) but differs by: apical epiphallic process longer and extending beyond lateral margins of epiphallus and with apex of process more strongly curved; mold of the spermatophore attachment plate transversely oval with anterior end broadly rounded (instead of lobular in the middle). It also differs by male ninth abdominal tergite much more elongated than supra-anal plate (shorter in M. pallidulus) and with a distinct longitudinal fissure in middle (absent in M. pallidulus); and by male metanotal gland.

The new species is also similar to M. bicolor (Haan, 1844) from Java, M. luzoni Gorochov, 2003 from Batangas in Luzon Island but differs by epiphallus distinctly slenderer, apical epiphallic process (term sensu Gorochov, 2003) larger and more strongly curved with apex acute and hooked (not strongly curved and without hooked apex in M. bicolor and shorter and faintly curved in M. luzoni); apical part of guiding rod (= rachis) with widened apex more longitudinally oblong and well surpassing posterior apex of epiphallus (transversely oblong in M. bicolor and rounded in M. luzoni); ectoparameres longer, also surpassing posterior end of epiphallus and more strongly curved at apex than M. bicolor and M. luzoni, and slenderer at apex than M. luzoni.

The mirror area of tegmen also differs with that of M. bicolor and M. luzoni: anterior half (with straight veins) as long as posterior half, unlike M. bicolor (anterior half shorter); transverse veins more similar to that of $M$. bicolor.

The new species also differs from other species from the Philippines: M. lineolatus Stål, 1877 (M. simodus Saussure, 1878) and M. splendidulus Stål, 1877 by clearly more uniform colouration of pronotum and legs; and M. strigatipes Bolívar, 1913 from Mindanao by colouration of head and structure of the male genitalia.

Description. Male. Body small for genus, very similarly sized as $M$. pallidulus, dorsoventrally compressed (Figs. 3A, 3B). Head slightly raised in posterior half behind eyes, flattened between eyes. Head rostrum 1.6 times as wide as scapus, 0.9 times as wide as eyes, with apex truncated (in dorsal 
view) (Figs. 3A, 3C). Scapus elongated. Eyes distinctly vertically oblong, barely projected laterally (Fig. 3B); median and lateral ocelli very oblong, positioned behind antennal scapus; median ocellus distinctly wider than long and located very slightly before lateral ocelli; lateral ocellus more beanshaped, located between scapus and anterior margin of eye (Fig. 3C). Maxillary palpi fairly stout, with apical (fifth) segment elongated, slightly more swollen, obliquely triangular (but its apex truncated) but shorter than third and subapical (fourth) segments (Fig. 3D). Posterior of eye above gena finely pubescent. Pronotal disc 0.6 times as long as wide, trapezoidal (Fig. 3A). Pronotal lateral lobe 1.2 times as long as tall, finely pubescent and margin with longer and thicker setae (Fig. 3D). Fore tibia with large and swollen conchate inner tympanum and large oval and open outer tympanum (Fig. 3E); fore and middle legs generally finely pubescent, with a few stout setae located usually along ventral margin; without subapical spines on ventral margins.

Male. Tegmen extending beyond abdominal apex; dorsal field barely longer than lateral field; mirror large, 2.2 times as long than wide, diamond-shaped with anterior and posterior parts narrowly angular, separated by a transverse vein in middle (Fig. 3A); with five harp veins (Fig. 3A); Sc with seven branches (Fig. 3B). Hind wings surpassing tegmen. Abdominal gland with posterior margin of fifth segment rectangularly, emarginated in middle, tubercle on sixth segment with anterior apex triangular and apex (Figs. 4A, 4B). Anal plate strongly and narrowly excised in middle, lateral of excision with dense strong setae pointing posteriorly; with a dorsal oval plate slightly surpassing lateral lobes, with posterior margin somewhat truncated (Fig. 4C). Male genitalia as shown in Figs. 4D-4F: epiphallus (ep) elongated, tapering slightly posteriorly, at posterior end excised deeply and broadly with two strongly sclerotized apical epiphallic processes (ep.p) produced at base of excision, pointing externally; apical epiphallic process large, extending beyond lateral margin of epiphallus, curved anteriorly at apex into a hook-like acute apex. Ectoparameres (ecp) producing slightly beyond apex of epiphallus, slender, slightly curved with apex subacute. Rachis (= guiding rod) with apical process (p.ra) produced well beyond apex of epiphallus, enlarged at apex, with a dorsal lobe bent anteriorly. Formula (f) very slender and elongated, forked at posterior end. Mold of the spermatophore (m.sp) attachment plate with anterior end broadly rounded with two pyriform lateral lobes joined together by a narrow 'bridge' in the middle; sits at base of rachis. Endoparameral apodeme (ap) very long slender and straight, surpassing anterior end of formula. Rami slightly longer than epiphallus, slightly curved at anterior end.

Female (Fig. 5). Body structure similar to that of male but with following differences: tegmen with nine longitudinal veins joined cross veins. Subgenital plate about as long as wide, posterior margin roundly excised, base of excision somewhat straight, lobe lateral of excision rounded (Fig. 5C). Ovipositor very short, surpassing tegmen but not hindwings (Fig. 5D).

Colouration. Head generally red brown, distinctly darker dorsally; scapus and pedicel red brown, darker dorsally; maxillary palpi and clypeus red brown, slightly darker at the apex. Pronotum also red brown but distinctly paler than dorsum of head. Tegmen in male pale yellow brown, unicolourous; in female pale yellow brown in dorsal field, dark red brown lateral field ventrad of Sc. Fore and middle legs generally red brown, darker in female. Hind femur whitish, with three broad dark red brown bands, all with irregular margins, one at the base, one slightly behind middle (broadest) and one at the knee; hind tibia red brown. Tergites generally yellow brown, sternites generally pale whitish.

Measurements (in mm). Male holotype: $\mathrm{BL}=11.0 ; \mathrm{PL}=1.6 ; \mathrm{PW}=2.5 ; \mathrm{TL}=10.1 ; \mathrm{HWT}=2.4$. Female allotype: $\mathrm{BL}=12.2 ; \mathrm{PL}=2.0 ; \mathrm{PW}=2.8 ; \mathrm{TL}=12.2 ; \mathrm{HWT}=3.9 ; \mathrm{HFL}=8.1 ; \mathrm{HTL}=7.3 ; \mathrm{OL}$ $=4.2$.

Etymology. This species is named after the type locality, Laguna in Luzon; noun in apposition. This new species from Laguna differs from similar looking species from nearby regions Bataan or Bulacan and Batangas.

\section{Genus Mistshenkoana Gorochov, 1990}

Remarks. 59 species are currently known and described from Australia (1 species), Borneo (4), Sumatra (3), Java (2), Lesser Sunda Islands (5), Malay Peninsula (5), New Guinea (10), Philippines (2), Solomon Islands (5), Southwestern Pacific Islands (17), Indochina (5) (Gorochov, 2006, Cigliano et al., 2020). Only Mistshenkoana gracilis (Chopard, 1925) and Mistshenkoana cicur (Saussure, 1878) 
were described from the Philippines (Gorochov, 2006). Species of Mistshenkoana are similar to species of Munda Stål, 1877 and Aphonoides Chopard, 1940 but differs from Munda by branches of $\mathrm{Sc}$ obliquely produced from Sc (instead of produced at the base of Sc and run nearly parallel to Sc) and from Aphonoides by more elongated male subgenital plate with more elongated spermatophore (Gorochov, 2006).

\section{Mistshenkoana matcha new species}

(Figs. 6-8)

\section{Gorochov (2006): 296 (Mistshenkoana ?gracilis)}

Material examined. Male holotype (UPLBMNH-ORT-1330), Philippines, Luzon Island, Laguna, Mount Makiling, N14.14767, E121.23094, 205.5 \pm 7.1 m.a.s.1., 11 April 2018, 2007 hours, on foliage of trees, coll. M. K. Tan, H. Yeo \& C. C. Lucañas, pinned and genitalia dissected (UPLBMNH).

Paratypes. 1 male (UPLG.19.16), Philippines, Luzon Island, Laguna, Paete, Barangay Ilaya, UP Land Grant, N14.40005, E121.54313, $365.8 \pm 8.3$ m.a.s.1., 1032 hours, 12 May 2019, coll. M. K. Tan, J. B. Baroga-Barbecho and S. A. Yap, pinned and genitalia dissected; 1 male, same locality, 6-7 September 2019, coll. J. B. Baroga-Barbecho \& C. C. Lucañas, pinned and genitalia dissected (ZRC).

Other material examined. 1 male, Philippines, Luzon Island, Laguna, Mount Makiling, coll. C. Baker (NHMUK).

Diagnosis. The new species differs from congeners by the combination of these characters: distinct paler colouration of body compared to wings and colour difference between lateral field and dorsal field of tegmen; shapes of apical epiphallic process and ectoparameres.

Comparison with congeners. We compared our specimens with the images of $M$. gracilis female allotype (MNHN-EO-ENSIF6739) from northwest Panay and male holotype (MNHN-EOENSIF6738) from Butuan, Mindanao in MNHN online collection and M. ?gracilis from Mount Makiling, Luzon (sensu Gorochov, 2006).

The specimens we collected differ from the M. gracilis holotype by distinct paler colouration of the body compared to tegmina and colour difference between lateral field and dorsal field of tegmen; cells between $\mathrm{M}$ and $\mathrm{R}$ infumated white near basal part of tegmen. Our specimens also differ distinctly from the $M$. gracilis allotype by pale yellow colouration (especially the head, pronotum and legs; rather than pale brown), absence of distinct dark spots on legs (although presence of a few on hind femur); fastigium not darkened; presence of faint longitudinal medial stripe on pronotum dorsum; presence of distinct darkish humeral stripe running from their base to their distal part and distinct colour difference between tegmen and rest of body; dorsal field of tegmen without markings on the cross-veins; cells between M and R infumated white near the basal part of the tegmen; cross-veins of lateral field of tegmen white.

The specimens we collected from Mount Makiling and Paete mostly resemble $M$. ?gracilis from Mount Makiling, Luzon (sensu Gorochov, 2006): dorsal surface of hind tibia with large dark spot in the middle; distinct colour difference between tegmen and rest of body and distinct darkish humeral stripe running from their base to their distal part. Likewise, the male genitalia are also indistinguishable between these specimens.

Therefore, it is possible that M. ?gracilis from Mount Makiling (sensu Gorochov, 2006) or the two female syntypes from Mount Makiling (sensu Chopard, 1925) belong to a different undescribed species from the types from Panay.

This species also differs from M. cicur (Saussure, 1878) from Luzon by pale colouration (especially the head, pronotum and legs), presence of faint longitudinal medial stripe on pronotum; pronotal lobe without dark transverse stripe along hind margin of pronotum; presence of dark lateral stripe on tegmen and distinct colour difference between tegmen and rest of body; cross veins on tegminal not white.

This species also resembles M. bilineata (Chopard, 1954) from Java by pale colouration and faint longitudinal medial stripe on pronotum but differs by shape of phallus (more elongated and slenderer epiphallus than $M$. bilieanta) and absence of dark stripe around tegminal dorsal field. 
Description. Male. Body typical of genus (Figs. 6, 7). Head rostrum 1.3 times as wide as scapus, 0.8 times as wide as eye, with apex truncated (in dorsal view) (Fig. 7C). Scapus elongated (Fig. 7B). Eyes distinctly vertically oblong, projected anteriorly (Figs. 7B, 7C); median and lateral ocelli very oblong; median ocellus distinctly wider than long and located between scapi; lateral ocellus between postero-inner margin or scapus and anterior margin of eye. Maxillary palpi cylindrical, with apical (fifth) segment elongated, obliquely swollen in middle with truncated apex, longer than third and subapical (fourth) segments; subapical segment slightly widened apically, shorter than third segment (Fig. 7D). Posterior of eye above gena finely pubescent. Pronotal disc 0.9 times as long as wide, anterior margin straight, posterior margin distinctly angular in middle (Fig. 7C). Pronotal lateral lobe 1.4 times as long as high, finely pubescent and margin with longer and thicker setae (Fig. 7B). Fore tibia with large oval and open inner tympanum and without outer tympanum; fore and middle legs generally finely pubescent, with a few stout setae located along ventral margin; without subapical spines on ventral margins.

Male. Tegmen extending beyond abdominal apex; dorsal field longer than lateral field; dorsal field with four main longitudinal veins; basal most vein splits at base on anal side and in middle on basal side; latter splits again in middle at anal side (Fig. 7E). Lateral field with many cross veins (some of which fused together) between M and Sc (Fig. 7A); Sc with 5 branches with a few crossveins between branches (Fig. 7A). Hind wings surpassing tegmen. Male genitalia as shown in Fig. 8: epiphallus (ep) elongated, tapering slightly posteriorly, divided into two parts at posterior end and angularly and narrowly excised; posterior end produced into apical epiphallic process. Apical epiphallic process (ep.p) in dorsal view flattened, triangular and pointing posterior-externally with apex obtuse, posterior-inner margin with dense setae; in lateral view with dorsal margin straight and ventral margin concave, apex truncated. Ectoparameres (ecp) in dorsal view elongated, very slender and narrowly forked at posterior end, basally enlarged and appear flattened. Rachis (ra) (= guiding rod) small, slender and straight, with apex acute.

Female. Unknown.

Colouration. Head, pronotum and legs generally yellow green when alive, pale yellow when drypinned; tegmen with distinctly different colouration as body. Scapus and antennae with tint of brown. Maxillary palps generally pale, with apical segment darker. Pronotal dorsal disc with anterior and posterior margins brown in middle, with a faint darkened median longitudinal band. Lateral lobe pale, with margins brown. Fore and middle femora yellow green, tibiae and tarsi pale brown. Hind femur yellow green with some small black spots dorsally; knee brown. Hind tibia yellow green (typically darker than hind femur) with a few small black spots, with a broad spot slightly after middle. Tegmen with dorsal field brown, with veins slightly darker; area between $\mathrm{M}$ and $\mathrm{R}$ including veins black, darkest in middle; area between R and Sc infumated white at basal half, apical half transparent with cross veins infumated white; Sc and branches brown with white margins, cross veins white. Hind wings with cross-veins infumated darkened. Abdominal tergite yellow green, sternite white.

Measurements (in mm). Male $(\mathrm{n}=2)$ : $\mathrm{BL}=11.4-11.6 ; \mathrm{PL}=2.2-2.3 ; \mathrm{PW}=2.4-2.5 ; \mathrm{TL}=13.3-$ 13.5; $\mathrm{HWT}=4.1-4.3 ; \mathrm{HFL}=9.9 ; \mathrm{HTL}=9.9$.

Etymology. The species name refers to the matcha (tea green) coloured body (including head, pronotum and legs) when alive, which is unique in this species compared to sympatric congeners and related species from the Philippines; noun in apposition.

\section{Mistshenkoana gracilis (Chopard, 1925)}

(Figs. 9, 10)

Chopard (1925): 327; Chopard (1929): 117; Chopard (1968): 400; Gorochov (1990): 21; Ichikawa et al. (2000): 278

Type material examined (images). Male holotype (MNHN-EO-ENSIF6738, MNHN online collection), Philippines, Mindanao, Butuan, coll. P. I. Baker; female allotype (MNHN-EOENSIF6739, MNHN online collection), Philippines, Western Visayas, Northwest Panay, coll. P. I. Baker. 
Remarks. Whether the male holotype and female allotype from two different parts of the Philippines belong to the same species need to be verified. The holotype and allotype differ slightly by apical segment of maxillary palp distinctly enlarged in allotype but less so in holotype; pronotum and legs of holotype homogenously brown but with dark spots in allotype.

New materials collected from Paete and Mount Makiling show that sympatric species can have very similar external morphology, but different male genitalia and that sexual dimorphism is obvious in Mistshenkoana. This lends support that the differences in between holotype and allotype are likely to be species variations, especially since the specimens were collected from separate islands belonging to two biogeographic regions.

Notes made by Chopard (1925) about females of ' $M$. gracilis' from Luzon are probably also belonging to another species.

\section{Mistshenkoana cicur (Saussure, 1878)}

(Fig. 11)

Saussure (1878): 647; Bolívar (1889): 430; Casto de Elera (1895): 222; Kirby (1906): 104; Bruner (1915): 266; Chopard (1968): 410; Gorochov, 2006: 275

Type material examined (images). Female holotype (DORSA-BG00016S01), Luzon, coll. Pfeiffe (MfN).

\section{Mistshenkoana sp. 1}

(Fig. 12)

Material examined. 1 female (UPLG.19.54), Philippines, Luzon Island, Laguna, Paete, Barangay

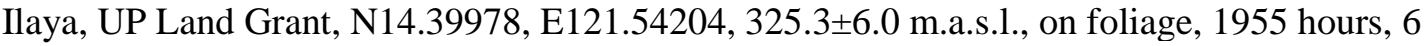
September 2019, coll. M. K. Tan, J. B. Baroga-Barbecho, C. C. Lucañas and S. A. Yap, pinned.

Remarks. The female specimen resembles $M$. gracilis female allotype from Panay and $M$. cicur female holotype from Luzon; but differs from $M$. cicur holotype by slightly more numerous crossveins between $\mathrm{R}$ and $\mathrm{Sc}$, with slightly thicker infumation; subgenital plate with posterior margin truncated and not narrowly excised in the middle. It is also differs from M. gracilis female allotype by fewer spots on the body (including head, pronotal dorsal disc and legs); more numerous and finer cross-veins between R and Sc and between Sc projections; shape of subgenital plate tapering to a narrowly concave apex (instead of broadly concave apex).

\section{Mistshenkoana sp. 2}

(Fig. 13)

Material examined. 1 male (UPLBMNH-ORT-1314), N14.185, E121.23227, $185.6 \pm 4.9$ m.a.s.l., 10 April 2018, 2000 hours, on foliage of trees coll. M. K. Tan, Huiqing Yeo, C. C. Lucañas and L. S. Crispolon (UPLBMNH).

Remarks. The male specimen is very similar to M. cicur (Saussure, 1878) female holotype in patterns and colours and tegminal venations (including cross veins on lateral and dorsal fields) but differs by $\mathrm{R}$ with five projections (instead of six). The specimen also differs from the holotype and allotype of M. gracilis from Panay by more and finer cross-veins between R and Sc and between Sc projections. This male specimen also differs from our female specimen from Paete (Mistshenkoana sp. 1) by fewer but thicker cross-veins between basal most longitudinal vein of the dorsal field and M; fewer cross-veins between R and Sc, with thinner infumation; R with five projections (instead of six).

\section{Mistshenkoana sursa new species}

(Figs. 14-17) 
Material examined. Male holotype (UPLG.19.12), Philippines, Luzon Island, Laguna, Paete, Barangay Ilaya, UP Land Grant, N14.40052, E121.54238, 309.2 \pm 5.4 m.a.s.1., 0933 hours, 12 May 2019, forest edge, coll. M. K. Tan, J. B. Baroga-Barbecho and S. A. Yap, pinned and genitalia dissected (UPLBMNH).

Paratypes. 1 female (UPLG.19.15), same locality, N14.40025, E121.54202, 320.3 \pm 5.9 m.a.s.1., 0958 hours, 12 May 2019, forest edge coll. M. K. Tan, J. B. Baroga-Barbecho and S. A. Yap, pinned; 1 male (UPLG.19.31) and 1 female (UPLG.19.32), Philippines, Luzon Island, Laguna, Paete, Barangay Ilaya, UP Land Grant, N14.39622, E121.56037, 405.2 \pm 5.3 m.a.s.1., 1448 hours, 12 May 2019, coll. M. K. Tan, J. B. Baroga-Barbecho and S. A. Yap, pinned (ZRC).

Diagnosis. This new species differs from congeners by the combination of these characters: apical (fifth) segment elongated, but not widened apically with apex rounded; epiphallus stout with apical epiphallic process bent perpendicular at base from epiphallus; apical epiphallic process pointing dorsad, slender and in middle bent angularly in lateral view, in dorsal view curved, pointing externally with obtuse apex in anterior view.

Remarks on material. The new species shares many morphological similarities from Mistshenkoana sp. 2. We can identify the female materials to belong to the males of this new species, instead of Mistshenkoana sp. 2 by this inference: the males (UPLG.19.12 and 31) collected from the same place but different time have identical genitalia. Since a pair of this species were found in the pre-copulation stage (i.e., UPLG.19.31, 32), we can identify the female of this species reliably. By comparing the morphology among the females, we can identify the female (UPLG.19.15) to also belong to this species, despite some variations in the tegminal cross-veins and branches of Sc.

Comparison with congeners. The male genitalia is typically similar to species with stout epiphallus with slender apical epiphallic process pointing dorsad. Genitalia is most similar to $M$. pileata Gorochov, 2008 from Solomon Islands by shape of epiphallus and apical epiphallic process but differs by shape of ectoparameres and spermatophore.

Genitalia differs from that of $M$. tembelingi Gorochov, 2007 from Malay Peninsula, $M$. pangrango Gorochov, 2007 from Java, M. asymmetrica Gorochov, 2008 from New Guinea, $M$. beybienkoi Gorochov, 1990 from Lesser Sunda Islands, M. erromango Gorochov, 2008 from Vanuata and M. yaeyamensis Oshiro, 1998 from islands off Japan by apical epiphallic process bent perpendicular at base from epiphallus and more angularly bent in middle (in lateral view) and shape of ectoparameres; from M. belokobylskiji Gorochov, 2006 and M. nhachangi Gorochov, 2007 from Vietnam by longer and more slender (from lateral view) apical epiphallic process and shape of ectoparameres; from M. caudatus (Bey-Bienko, 1966) from Komodo Island by middle of anterior margin of epiphallus with distinct excision; from M. kolobagara Gorochov, 2008 and M. rennell Gorochov, 2008 from Solomon Islands by longer apical epiphallic process (otherwise very similar by bent perpendicular at the base from epiphallus and more angularly bent in middle in lateral view).

Description. Male. Body typical of the genus (Figs. 14A, 14B, 17). Head rostrum somewhat elongated, 1.7 times as wide as scapus, 1.1 times as wide as eyes, with apex obtusely rounded (in dorsal view) (Fig. 14C). Scapus elongated. Eyes distinctly vertically oblong, projected anteriorly (Figs. 14C, 14D); median and lateral ocelli very oblong; median ocellus distinctly wider than long and located very slightly before lateral ocelli; lateral ocellus longer than wide, located between scapus and anterior margin of eye. Maxillary palpi cylindrical, with apical (fifth) segment elongated, but not widened apically with apex rounded, longer than subapical (fourth) segments but subequal length as third segment; subapical segment slightly widened apically, shorter than third segment (Fig. 14D). Posterior of eye above gena finely pubescent (Fig. 14D). Pronotal disc 0.9 times as long as wide, anterior margin straight, lateral margin slightly widening apically (more obvious at apical third), posterior margin distinctly angular in middle (Fig. 14C). Pronotal lateral lobe 1.4 times as long as high, finely pubescent and margin with longer setae (Fig. 14D). Fore tibia with very large oval and open inner tympanum, outer tympanum absent; fore and middle legs generally finely pubescent, with a few stout setae located usually along ventral margin; without subapical spines on ventral margins.

Male. Tegmen extending beyond abdominal apex; dorsal field longer than lateral field; dorsal field with four main longitudinal veins; basal most vein splits at base on anal side and in middle on basal side; latter splits again in middle at anal side (Fig. 14A). Lateral field with few widely spaced cross veins (some of which fused together) between M and Sc (Fig. 14B); Sc with 5 branches with a 
few cross-veins between branches (Fig. 14B). Hind wings surpassing tegmen. Male genitalia as shown in Fig. 15: epiphallus stout compared to M. matcha sp. nov. and Mistshenkoana sp. 2, anterior end truncated with a broad rounded excision in middle, tapering slightly posteriorly; posterior end produced into apical epiphallic process, process bent perpendicular from epiphallus. Apical epiphallic process (ep.p) pointing dorsad, slender and in middle bent angularly in lateral view, in dorsal view curved, pointing externally with obtuse apex in anterior view, apex with a few setae. Ectoparameres slender. Rachis (= guiding rod) small, slender and straight, with apex acute. Endoparameral apodeme slightly surpassing anterior margin of epiphallus. Rami perpendicular to epiphallus.

Female. Very similar to male, including tegminal venations (Figs. 16A, 16B). Subgenital plate 1.5 times as long as wide, tapers slightly posteriorly, with apex concave (Fig. 16C). Ovipositor with apex as in Fig. 16D.

Colouration. Head, pronotum and legs generally brown. Head dorsum slightly darker. Scapus and antennae pale brown. Ventral of eye with a black vertical band. Maxillary palps generally pale. Pronotal dorsal disc pale brown, with faint darkened patterns (Fig. 14C). Lateral lobe pale brown. Fore and middle femora pale, with some black/ dark brown spots at apical half, tibiae brown with dark spots. Hind femur pale brown with some small dark brown/ black spots dorsally; knee brown. Hind tibia brown, with dorsal surface with an irregular black longitudinal stripe. Tegmen brown, with longitudinal veins slightly darker; and cross-veins pale. Hind wings with cross-veins infumated darkened. Abdominal tergite and sternite white.

Measurements (in mm). Male holotype: $\mathrm{BL}=11.7 ; \mathrm{PL}=1.9 ; \mathrm{PW}=2.1 ; \mathrm{TL}=10.0 ; \mathrm{HWT}=5.4$; $\mathrm{HFL}=8.6 ; \mathrm{HTL}=8.1$. Females $(\mathrm{n}=2): \mathrm{BL}=9.8-10.8 ; \mathrm{PL}=1.8-2.0 ; \mathrm{PW}=2.5-2.9 ; \mathrm{TL}=11.6-12.5$; $\mathrm{HWT}=0.9 ?-1.8 ; \mathrm{HFL}=8.8-9.8 ; \mathrm{OL}=7.7-8.4$.

Etymology. The species name refers to the apical epiphallic process pointing dorsad, perpendicular from the epiphallus (sursum $=$ upward in Latin).

Natural history. A female was photographed feeding on flowers. Such behaviour is also not previously recorded (Tan et al., 2017).

\section{Acknowledgements}

The authors thank Huiqing Yeo and Cristian C. Lucañas for assistance in fieldwork in Mount Makiling; the UP Laguna Land Grant management, particularly Pablo Quilao and the forest guards for the security and accommodation during fieldworks; the UPLBMNH for allowing us to access their orthopteroid collections, especially for the assistance of Orlando L. Eusebio and Cristian C. Lucañas during the visit of MKT at UPLBMNH. The authors also thank Marion Depraetere for the photographs of the type specimens of Mistshenkoana gracilis on the MNHN Online Collection. The work in the Philippines was granted by the Orthoptera Species File Grant 2018 under the taxonomic research project with the title "Advancing biodiversity informatics of Orthoptera from the Philippines".

\section{References}

Baroga, J.B., Yap, S.A. \& Robillard, T. (2016) Two new species of Eneopterinae crickets (Orthoptera: Gryllidae) from Luzon, Philippines. Zootaxa, 4139 (1), 93-105.

https://doi.org/10.11646/zootaxa.4139.1.5

Baroga-Barbecho, J.B., Yap, S.A., Tan, M.K. \& Robillard, T. (2019) Taxonomic review of the genus Paranisitra Chopard (Orthoptera: Gryllidae: Eneopterinae: Nisitrini) with description of a new species from Mindanao. Zootaxa, 4568 (1), 81-96. https://doi.org/10.11646/zootaxa.4568.1.5

Bolívar, I. 1889. Enumeración de Grílidos de Filipinas. Anales de la Sociedad Española de Historia Natural, 18, 415-431.

Bruner, L. (1915) Preliminary catalogue of the Orthopteroid insects of the Philippines Island. The University Studies of the University of Nebraska, 15 (2), 195-281.

Casto de Elera. 1895. Ortópteros. Catálogo sistemático de toda la fauna de Filipinas, 2, 189-223 
Chopard, L. (1925) Descriptions de Gryllides nouveaux. Annales de Société entomologique de France, 94, 291-332.

Chopard, L. (1929) Spolia Mentawiensia: Gryllidae. Bulletin of the Raffles Museum, 2, 98-118.

Chopard, L. (1937) Notes sur les Gryllides et Tridactylides du Deutsches Entomologisches Institut et description d'espèces nouvelles. Arbeiten über Morphologische und Taxonomische Entomologie aus Berlin-Dahlem, 4, 136-152.

Chopard, L. (1968) Family Gryllidae: Subfamilies Mogoplistinae, Myrecophilinae, Scleropterinae, Cachoplistinae, Pteroplistinae, Pentacentrinae, Phalangopsinae, Trigonidiinae, Eneopterinae; Family Oecanthidae, Gryllotalpidae. In: Beier, M. (ed.), Orthopterorum Catalogus. Volume 12. Uitgeverij Dr. W. Junk N. V.'s, Gravenhage. Pp. 215-500.

Cigliano, M.M., Braun, H., Eades, D.C. \& Otte, D. (2020) Orthoptera Species File online. Version 5 (5.0). Available from: http://orthoptera.speciesfile.org/HomePage/Orthoptera/HomePage.aspx (accessed 7 May 2020)

Desutter-Grandcolas, L. (2009) New and little known crickets from Espiritu Santo Island, Vanuatu (Insecta, Orthoptera, Grylloidea, Pseudotrigonidium Chopard, 1915, Phaloriinae and Nemobiinae p.p.). Zoosystema, 31 (3), 619-659. https://doi.org/10.5252/z2009n3a12

Gorochov, A.V. (1985) On the Orthoptera subfamily of Gryllinae (Orthoptera, Gryllidae) from eastern Indochina. In Medvedev, L.N. [Ed.]. Fauna i ekologiya nasekomykh Vetnama [The fauna and ecology of insects of Vietnam]. Pp. 9-17.

Gorochov, A.V. (1990) News of systematics and faunistics of Vietnam insects part 1. Trudy Zoologitscheskogo Instituta, Akademiia Nauk SSSR, Leningrad [ = Proceedings of the Zoological Institute, USSR Academy of Sciences, Leningrad], 209, 3-28.

Gorochov, A.V. (1996) New and little known crickets from the collection of the Humboldt University and some other collections (Orthopera: Grylloidea). Part 2. Zoosystematica Rossica, 5 (1), 29-90.

Gorochov, A.V. (2003) Taxonomy of Podoscirtinae (Orthoptera: Gryllidae). Part 2: Indo-Malayan and Australo-Oceanian Podoscirtini. Zoosystematica Rossica, 11 (2), 267-303.

Gorochov, A.V. (2006) Taxonomy of Podoscirtinae (Orthoptera: Gryllidae). Part 5: New IndoMalayan and Madagascan Podoscirtini. Zoosystematica Rossica, 15 (1), 33-46.

Gorochov, A.V. (2007[2006]) Taxonomy of Podoscirtinae (Orthoptera: Gryllidae). Part 6: IndoMalayan Aphonoidini. Zoosystematica Rossica, 15 (2), 237-289.

Gorochov, A.V. (2008) Taxonomy of Podoscirtinae (Orthoptera: Gryllidae). Part 7: AustraloOceanian Aphonoidini and geography of the tribe. Zoosystematica Rossica, 17 (1), 15-50.

Gorochov, A.V. (2015) Evolution and taxonomic significance of the copulatory apparatus in Ensifera (Orthoptera). Part 2: Male genitalia in Grylloidea. Zoosystematica Rossica, 24 (1), 31-41. https://doi.org/10.31610/zsr/2015.24.1.31

Gorochov, A.V. (2016) Taxonomic studies on the subfamily Landrevinae. Zoosystematica Rossica, 25 (1), 23-97.

Hollier, J., Bruckner, H. \& Heads, S. (2013) An annotated list of the Orthoptera (Insecta) species described by Henri de Saussure, with an account of the primary type material housed in the Muséum d'histoire naturelle de Genève, Part 5: Grylloidea. Revue Suisse de Zoologie, 120 (3), 445-535.

Ichikawa, A., Murai, T. \& Honda, E. (2000) Monograph of Japanese crickets (Orthoptera: Grylloidea). Bulletin of Hoshizaki Green Foundation, 4, 257-332.

Ingrisch, S. (2018) New taxa and records of Gryllacrididae (Orthoptera, Stenopelmatoidea) from South East Asia and New Guinea with a key to the genera. Zootaxa, 4510 (1), 1-278. https://doi.org/10.11646/zootaxa.4510.1.1

Kirby, W.F. (1906) Orthoptera Saltatoria. Part I. (Achetidae et Phasgonuridae). A Synonymic Catalogue of Orthoptera (Orthoptera Saltatoria, Locustidae vel Acridiidae). 2, i-viii, 1-562.

Ma, L., Gorochov, A.V., \& Zhang, Y. (2015) A new species of the genus Duolandrevus (Orthoptera: Gryllidae: Landrevinae) from China. Zootaxa, 3963 (3), 443-449. http://dx.doi.org/10.11646/zootaxa.3963.3.8

Otte, D. (1988) Bark crickets of the Western Pacific Region (Gryllidae: Pteroplistinae). Proceedings of the Academy of Natural Sciences of Philadelphia, 140 (2), 281-334.

Otte, D. \& Alexander, R.D. (1983) The Australian crickets (Orthoptera: Gryllidae). Monographs of the Academy of Natural Sciences of Philadelphia, 22, 1-477. 
Robillard, T. \& Yap, S.A. (2015) The Eneopterinae crickets from Leyte Island (Philippines) with description of two new species [Insecta: Orthoptera: Grylloidea: Gryllidae]. The Raffles Bulletin of Zoology, 63, 69-90.

Saussure, H. (1878) Mélanges orthoptérologiques. VI. fascicule Gryllides. Mémoires de la Société de Physique et d'Histoire Naturelle de Genève, 25 (2), 369-704 [505-834].

Skejo, J., \& Cabellero J.H.S. (2016) A hidden pygmy devil from the Philippines: Arulenus miae sp. nov.- - a new species serendipitously discovered in an amateur Facebook post (Tetrigidae: Discotettiginae). Zootaxa, 4067 (3), 393-393. http://dx.doi.org/10.11646/zootaxa.4067.3.7

Tan, M.K., Artchawakom, T., Wahab, R.A., Lee, C.-Y., Belabut, D.M. \& Tan, H.T.W. (2017) Overlooked flower visiting Orthoptera in Southeast Asia. Journal of Orthoptera Research, 26 (2), 143-153. https://doi.org/10.3897/jor.26.15021

Tan, M.K., Choi, J. \& Shankar, N. (2017) Trends in new species discovery of Orthoptera (Insecta) from Southeast Asia. Zootaxa, 4238 (1), 127-134. https://doi.org/10.11646/zootaxa.4238.1.10

Tan, M.K., Gorochov, A.V., Baroga-Barbecho, J.B. \& Yap, S.A. (2019c) A new species of Landrevinae (Orthoptera) from the Philippines, with notes on Endodrelanva and Endolandrevus (Orthoptera: Gryllidae; Gryllinae; Landrevini). Zootaxa, 4544 (2), 285-295. https://doi.org/10.11646/zootaxa.4462.3.2

Tan, M.K., Jin, X.-B., Baroga-Barbecho, J.B. \& Yap, S.A. (2020) Taxonomy and bioacoustics of Meconematinae (Orthoptera: Tettigoniidae) from Laguna (Philippines: Luzon). Zootaxa, 4732 (4), 527-544. https://doi.org/10.11646/zootaxa.4732.4.2

Tan, M.K., Ingrisch, S., Robillard, T., Baroga-Barbecho, J.B. \& Yap, S.A. (2018) New taxa and notes on spine-headed katydids (Orthoptera: Conocephalinae: Agraeciini) from the Philippines. Zootaxa, 4462 (3), 331-348. https://doi.org/10.11646/zootaxa.4462.3.2

Tan, M.K., Tumbrinck, J., Baroga-Barbecho, J.B. \& Yap, S.A. (2019a) A new species and morphometric analysis of Cladonotella (Tetrigidae: Cladonotinae). Journal of Orthoptera Research, 28 (2), 129-135. https://doi.org/10.3897/jor.28.32464

Tan, M.K., Ingrisch, S., Baroga-Barbecho, J.B. \& Yap, S.A. (2019b) New species of Ornebius (Orthoptera: Mogoplistinae) from Siargao Island of the Philippines. Zootaxa, 4590 (1), 166-176. https://doi.org/10.11646/zootaxa.4590.1.7

Tan, M.K., Baroga-Barbecho, J.B. \& Yap, S.A. (2019c) Taxonomic notes on Trigonidium (Trigonidiidae) and related groups with one new species from the Philippines. Zootaxa, 4564 (2), 573-587. https://doi.org/10.11646/zootaxa.4564.2.13

Tan, M.K. \& Kamaruddin, K.N. (2016) New taxa and notes on some Landrevinae (Orthoptera: Gryllidae) from Malay Peninsula. Zootaxa, 4162 (3), 559-570. https://doi.org/10.11646/zootaxa.4162.3.9

Tan, M.K. \& Wahab, R.A. (2017b) New taxa and notes on crickets of the subfamily Landrevinae (Orthoptera: Gryllidae) from Brunei Darussalam, Borneo. Zootaxa, 4365 (4), 440-454. https://doi.org/10.11646/zootaxa.4365.4.4

Yin, H. \& Liu, X.-W. (1995) Synopsis on the classification of Grylloidea and Gryllotalpoidea from China. 239 pp. 


\section{Figure captions}

FIGURE 1. Duolandrevus (Jorama) curtipennis male: live habitus (A), metanotal gland in dorsal view (B), abdominal apex in dorsal view (C), genitalia in dorsal (D), ventral (E) and lateral (F) views. Scale bars: $1 \mathrm{~mm}$.

FIGURE 2. Phaloria (Phaloria) modulator male: live habitus (A), tegmen in dorsal view (B), genitalia in dorsal (C), ventral (D) and lateral (E) views. Scale bar: $2 \mathrm{~mm}$.

FIGURE 3. Mnesibulus laguna n. sp. male holotype: habitus in dorsal (A) and lateral (B) views, face in anterior view $(C)$, head and pronotum in lateral view (D), anterior tympanum in anterior view (E). Scale bars: $2 \mathrm{~mm}$ (A, B), $1 \mathrm{~mm}(\mathrm{C}-\mathrm{E})$.

FIGURE 4. Mnesibulus laguna n. sp. male holotype: metanotal gland in dorsal views (A, B), abdominal apex in dorsal view (C), genitalia in dorsal (D), ventral (E) and lateral (F) views. Scar bars: $1 \mathrm{~mm}(\mathrm{~A}-\mathrm{C})$.

FIGURE 5. Mnesibulus laguna n. sp. female allotype: habitus in dorsal (A) and lateral (B) views, subgenital plate in ventral view (C), apex of ovipositor in lateral view (D). Scale bars: $5 \mathrm{~mm}$ (A, B), 1 $\mathrm{mm}(\mathrm{C}, \mathrm{D})$.

FIGURE 6. Mistshenkoana matcha $\mathbf{n}$. sp. males in their natural environment.

FIGURE 7. Mistshenkoana matcha n. sp. male: habitus in lateral view (A), head and pronotum in lateral (B) and dorsal (C) views, maxillary palps in lateral view (D), tegmen in dorsal view (E). Scale bars: $5 \mathrm{~mm}(\mathrm{~A}, \mathrm{E}), 1 \mathrm{~mm}(\mathrm{~B}-\mathrm{D})$.

FIGURE 8. Mistshenkoana matcha $\mathbf{n}$. sp. male genitalia in dorsal (A), ventral (B) and lateral (C) views.

FIGURE 9. Mistshenkoana gracilis male holotype in dorsal (A), ventral (B) and lateral (C) views, face in anterior view (D), label (E). Images from MNHN online collection by Marion Depraetere (http://coldb.mnhn.fr/catalognumber/mnhn/eo/ensif6738).

FIGURE 10. Mistshenkoana gracilis female allotype in dorsal (A), ventral (B) and lateral (C) views, face in anterior view (D), apex of ovipositor in lateral view (E), label (F). Images from MNHN online collection by Marion Depraetere (http://coldb.mnhn.fr/catalognumber/mnhn/eo/ensif6739).

FIGURE 11. Mistshenkoana cicur female holotype in dorsal (A), ventral (B) and lateral (C) views, subgenital plate in ventral view (D), apex of ovipositor in lateral view (E), label (F). Images from DORSA by S. Ingrisch.

FIGURE 12. Mistshenkoana sp. 1 female in its natural environment (A), habitus in dorsal (B) and lateral (C) views, subgenital plate in ventral view (D), apex of ovipositor in lateral view (E). Scale bars: $5 \mathrm{~mm}(\mathrm{~B}, \mathrm{C}), 1 \mathrm{~mm}(\mathrm{D}, \mathrm{E})$.

FIGURE 13. Mistshenkoana sp. 2 male habitus in dorsal (A) and lateral (B) views, genitalia in dorsal $(C)$, ventral (D) and lateral (E) views. Scale bars: $5 \mathrm{~mm}$.

FIGURE 14. Mistshenkoana sursa $\mathbf{n}$. sp. male habitus in dorsal (A) and lateral (B) views, anterior half of body in dorsal (C) and lateral (D) views, face in anterior view (E). Scale bars: $5 \mathrm{~mm}(\mathrm{~A}, \mathrm{~B}), 2$ $\mathrm{mm}(\mathrm{C}, \mathrm{D}), 1 \mathrm{~mm}(\mathrm{E})$.

FIGURE 15. Mistshenkoana sursa $\mathbf{n}$. sp. male genitalia in dorsal (A), lateral (B), anterior (C) and posterior (D) views, spermatophore in lateral view (E). 
FIGURE 16. Mistshenkoana sursa n. sp. female habitus in dorsal (A) and lateral (B) views, subgenital plate in ventral view (C), apex of ovipositor in lateral view (D). Scale bars: $5 \mathrm{~mm}(\mathrm{~A}, \mathrm{~B}), 1$ $\mathrm{mm}(\mathrm{C}, \mathrm{D})$.

FIGURE 17. Mistshenkoana sursa $\mathbf{n}$. sp. in its natural environment. 